\title{
PSYCHOLOGICAL CHARACTERISTICS OF ADOLESCENTS FROM FUNCTIONAL AND DYSFUNCTIONAL FAMILIES WITH FATHERS' ALCOHOLISM
}

\section{Ljiljana B. Simonović Grujić}

Secondary School "Bora Stanković"

Vranje, Serbia

UDK: 617.836 .1

\section{Summary}

Introduction. Growing up in dysfunctional alcoholic families is associated with the psychosocial development of children. Furthermore, family alcoholism rarely occurs without many forms of violence and aggression in the home. Family alcoholism is associated with mental health and parenting problems, and children experience a wide variety of long-term social adjustment and emotional difficulties, including behavioral problems.

Objective. The aim of the study is to determine whether growing up in a dysfunctional family, caused by father's alcoholism, is related to the achieved psychological maturity, achievement at school, internalizing, externalizing and behavioral problems and specific psychological characteristics of the adolescents (COAs) in comparison to the psychological characteristics of the adolescents from functional, non-alcoholic families (nonCOAs). 
Method. The study was evaluated 691 adolescent, aged 14-19 years, who were divided into two groups: experimental group included 397 participants from families with alcoholism and control group included 294 participants from functional families where no alcoholism or any other type of mental disorders of parents were set up. Based on treatment alcoholism the experimental group divided into two sub-samples: 142 respondents from families with treated alcoholism, and 255 participants from untreated alcoholism families. For screening of the conative functions of the personality, was used the battery of Conative Personality Dimensions (CON-6), Psychological Maturity is measured by the Scale Latent Maturity (SLM), Psychosocial dimensions were tested by Questionnaire for psychosocial characteristics of adolescents and family (CPRS-R), whereas intellectual abilities were examined by Test reasoning characters (TRL). Canonical discriminate analysis was used in order to determine the differences in psychological characteristics of the personality of adolescents from alcoholic and non-alcoholic families.

Results. The study obtained statistically significant difference between psychological characteristics of adolescents from alcoholics and non-alcoholics families. The specific psychological characteristics of the adolescents from alcoholic family are: a lower level of mature personality development, reduced coop- eration, expression of aggressive and dissociative reactions. The adolescents from families with treated alcoholic family members have expressed: truancy, conflicts with peers, suicide behavior, running away from home, activity disorders in comparison to the peers from families with untreated alcoholism. Growing up in dysfunctional alcoholic family systems is associated with the formation of a specific psychological functioning with externalizing, internalizing and behavioral problems.

Conclusions. The current study suggests that growing up in a dysfunctional alcoholic family is associated with the development of specific personality characteristics of adolescent, in comparison to non-COAs peers.

\section{Key words:}

dysfunctional, family, psychological, adolescents, alcoholism 


\section{INTRODUCTION}

Dysfunction of family system is established by family disturbance diagnosis. In the classification of mental and behavioral disorders of the World Health Organization (ICD X) alcoholism and domestic consequences of alcoholism are defined in F 10, a group of disorders dependence and alcohol abuse, and F-90 -F98-emotional and behavioral disorders in childhood and adolescence of children from dysfunctional families ${ }^{[1,2]}$.

The theoretical and conceptual basis of the research is a family system theory, which defines an alcoholic family as a dysfunctional system, caused by dysfunction of a sub-system- an alcoholic, in which multiply damaged spouse differentiation leads to the impossibility of developing differentiation in children growing up in these families ${ }^{[3]}$. Dysfunction of certain alcoholic family system is enhanced by the presence of some other psychiatric diagnoses of parents. In addition to alcoholism or alcohol abuse, at $37 \%$ of alcoholics is determined the existence of the psychology deceases ${ }^{[4]}$. The present psychopathology of alcoholic father was later observed in the behavior of their children ${ }^{[5]}$.

Growing up in a dysfunctional alcoholic system disrupts the psychosocial development of children from these families, causing the formation of active, externalized, and passive, internalized symptoms $s^{[6,7]}$.
Results of research on the consequences of growing up in alcoholic families indicate that the externalized symptoms in children and adolescents are associated with parental diagnosis, especially with antisocial personality disorder and the presence of a high level of stress in the family: aggression ${ }^{[8]}$, impulsive behavior, ADHD, attention deficit disorder and behavior, ODD-attention deficit disorder / hyperactivity disorder, CD-authority issues ${ }^{[9,10]}$, disorders of habits (thumb sucking, night terrors), aggressiveness, impulsivity ${ }^{[11]}$, hyperactivity, bulimia and delinquent behavior $^{[12,13]}$.

Internalized symptoms of children and young people from alcoholic families are: depression, anxiety, hypersensitivity, learned helplessness and fear and acute condition ${ }^{[7,13-15]}$.

Growing up in alcoholic families with various forms of violence influences the development of expressed symptoms of post-traumatic stress disorder, due to the presence of children to murders, suicides or fights parents. Further development of posttraumatic symptomatology ${ }^{[16]}$, in young leads to the appearance of: depression, suicidality ${ }^{[17]}$, anxiety, drug addiction, delinquency and somatic problems ${ }^{[15,18]}$.

Children of alcoholics (COAs) reported poorer school performance, a higher substance use(cigarettes, marijuana, drinking), and more mental health difficulties (emotional symptoms, 
conduct problems, suicidal tendencies, marital disorder ${ }^{[18,19]}$.

In forming a sense of identity, youth from alcoholic family have a very low self-esteem, feelings of inadequacy, inferiority, lower socialization, individualization and emotional maturity ${ }^{[20,21]}$. Lack of inadequate identification models for boys, from alcoholic families, has resulted in difficulties in the construction of sexual roles ${ }^{[22]}$.

For young people from alcoholic families, it has been established 2-10 times greater risk for alcoholism and other forms of addiction (cigarettes, marijuana), in relation to young people from non-alcoholic families ${ }^{[7,8,11,23,24]}$.

Emotional problems, attention disorder problems, and relations to authority of youth from alcoholic families are accompanied by difficulties in intellectual development and emphasized school problems ${ }^{[25,26]}$.

Children of alcoholics, who have normal intelligence, at school age, they have less opportunity to pay attention, difficulty in monitoring guidelines and establishing relations ${ }^{[27]}$.

The specificity of the psychological profiles of young people from alcoholic families has led some researchers to propose the introduction of the concept of "children in risk", because it is possible to predict the emotional, intellectual and social problems in childhood, youthful and mature age ${ }^{[28]}$.

\section{OBJECTIVE}

The aim of the study is to determine whether growing up in a dysfunctional family, caused by father's alcoholism, is related to the achieved psychological maturity, achievement at school, internalizing, externalizing and behavioral problems and specific psychological structure of the adolescents from such a family, which is different from the personality profile of the non-COAs peers. The practical aim of the study will be seen in the possibility of application of preventive mental hygiene, counseling and therapeutic measures, so as to mitigate the negative impact of a dysfunctional family on the personality's psychosocial development.

\section{METHOD}

The sample and procedure

The study was conducted on a sample of 691 test subjects, aged 14-19 ( $M=17.2$, $\mathrm{SD}=1.23)$. The control group consisted of 294 (43\%) adolescents from the Secondary School in Vranje, who were divided on the basis of a preliminary research combination type questionnaire, which classified those test subjects in whose families there was no record of parental alcoholism or any other psychopathology. The experimental group consisted of a sample of 397 (57\%) participants, who were divided into two sub-samples: E1=142 (39\%) adolescents 
from the families whose parents were patients or hospitalized in a psychiatric hospital and Institute for Mental Health in Vranje, Public Health Department of Clinical Center Niš and the Hospital for addictions in Belgrade, and E2 $=255$ (61\%) adolescents from the families with untreated alcoholism, who were categorized by the Questionnaire for determining psychological and social pathology of family members - Revised Conners Parent Rating Scale (CPRS-R) ${ }^{[29]}$. There were no differences between the groups by the age ( $t(198)=-1.09$, non-significant). The testing was conducted by psychologists and specialist teachers, who did therapeutic work with the parents and the adolescent or the adolescent only. The testing was done with prior permission of the directors of these institutions and consent of the parents and/or the adolescents. The survey was anonymous. Testing total test material took 1.5 to 2 hours. To test the Test of Reasoning Images (TRL) ${ }^{[30]}$, a test of general intelligence, was prescribed to last 30 minutes, with specific instructions, SLM (Scale of Latent Maturity ${ }^{[31]}$ and KON-6 (Test Conative Functioning Personality $^{[32]}$. was filled by the test subjects in 30 minutes, while answering the Questionnaire for self-assessment of family relationships and psychosocial development (CPRS-R) lasted up to 15 minutes. The survey was conducted during the period from 2007 to 2011.
The study examined the differences in the profile of the personality of the adolescents from the functional and dysfunctional alcoholic family in the following scope: general intellectual ability, the results obtained on TRLTest of reasoning characters ${ }^{[2]}$. It contains 45 items. In this study, reliability estimates for the scores were very high $\alpha=.96$. Latent maturity, measured by the Scale of Latent Maturity with five sub-scales: cooperation with people, trust in people, selflessness, frustration tolerance, attitude toward the future ${ }^{[30]}$. It contains 133 items. In this study, reliability estimates for the scores were $\alpha=.92$. Conative dimensions, measured by the KON-6Conative Personality Dimensions, are: reaction activity-introversion/extroversion, psychosomatic reactions, anxiety-defense reactions, aggressive-response attacks, dissociative reactions, integrative reaction-social adaptation $^{[31]}$. It contains 180 items. In this study, reliability estimates for the scores were $\alpha=.96$. The Revised Conners Parent Rating Scale (CPRS-R), measured attitude towards school (academic achievement, absenteeism, teaching, respect for school rules of behavior, attention problems, lack of interest in school); problems and psychosocial development (drinking problem and drunkenness, hyperactive behavior, lying, phobias, stubbornness, drug abuse, running away from home, suicide behavior) ${ }^{[32]}$. It contains 42 items. In this 
study, reliability estimates for the scores were very high $\alpha=.94$.

Data analysis was performed using the software package SPSS version 11.5. The results are presented by using the method of statistical inference: canonical discriminated analysis. The significance of differences was assessed by: Box's Test of Equality of Covariance Matrices, Chi-square test and One-Way ANOVA. The level of statistical significance is less than $1 \%(\mathrm{p}<0.001)$ and $5 \%$ $(\mathrm{p}<0.05)$.

\section{RESULTS}

To determine the existence or non-existence, the difference between the sub-samples, compared to the tested characteristics is determined by the canonical discriminated analysis (Table 1). Two discriminated functions were obtained. Based on Chi-square test of significance, we can conclude that the sub-samples in the study are significantly different, statistically speaking ( $\mathrm{p}<0.001$ ), in the personality's profile. Between the samples of the adolescents from families with treated / untreated alcoholism family and the adolescents from non-alcoholic families, there are significant differences in the studied characteristics, containing discriminative function: association with humans, frustration tolerance, trust in people, selflessness, attitude towards the future, the maturity of personality, psychoso- matic reactions, anxiety, aggression, dissociative reactions, integrative reactions, success in school, absences from school which were justified, drinking alcohol and drunkenness, problems of paying attention, disinterested students, hyperactivity, lying, phobias, obstinacy, conflicts with peers, drug abuse, punishment in school, running away from home and suicide behavior.

We used the Box's M-test for testing the homogeneity of the covariance matrix of sub-samples (Table 2). After the Box's M-test has been obtained, it is statistically significant (Box $M=1570.755$, $\mathrm{p}=0.000$ ) and shows that the covariance matrixes are heterogeneous between the groups, classification of the test subjects on the basis of the obtained functions is performed on the covariance matrix within the groups.

Table 3 shows its distinctive values, the percentage of intergroup variance which refers to the given intrinsic value, i.e., the percentage of the overall discriminatory power of a set of variables referring to the given discriminated functions, canonical correlation and the results of testing the significance of the discriminated function (canonical correlation) using Bartlett's Hi- square test.

The two discriminated functions have been obtained. Based on the significance of the chi-square test (chi-square $=666.443, p=0.001$ for the first function and the chi-square $=139.336, \mathrm{p}=0.001$ for the second function) it was estimat- 
ed that the sub-samples in the study are statistically significantly different in personality profile.

The data in Table 4 shows two discriminated functions which were obtained.

The first discriminated function builds a stack feature which are strongly expressed: latent immaturity $(-0.623$, $\mathrm{p}<0.05)$ and non-cooperation with people $(-0.552, \mathrm{p}<0.05)$, medium predominantly aggression $(0.459, \mathrm{p}<0.05)$, a system for the coordination of regulatory functions-dissociative reaction (0.449, p <0.05), obstinacy $(0.434, p$ $<0.05)$, non-social adaptation $(0.411, \mathrm{p}$ $<0.05)$, the tendency for psychosomatic reactions $(0.398, \mathrm{p}<0.05)$, lack of commitment to the future $(-0.397, \mathrm{p}<05)$, selfishness $(-0.391, \mathrm{p}<0.05)$, anxiety reactions $(0.361, \mathrm{p}<0.05)$, the tendency for getting drunk $(0.358, \mathrm{p}<0.05)$, lack of trust in people $(-0.344, \mathrm{p}<0.05)$, phobic reactions to certain stimuli $(0.317$, $\mathrm{p}<0.05)$, attention problems $(0.306, \mathrm{p}$ $<0.05)$, propensity for lying $(0.281, \mathrm{p}$ $<0.05)$, reduced Frustration tolerance $(-0.279, \mathrm{p}<0.05)$, tendency for drinking $(0.270, \mathrm{p}<0.05)$, hyperactive behavior $(0.264, \mathrm{p}<0.05)$, lower success at school $(-0.264, \mathrm{p}<0.05)$, punishment in school for disrespecting the rules of conduct (0.263, p <0.05), mildly expressed: lack of interest in school $(0.189, \mathrm{p}<0.05)$ and tasting drugs $(0.106, \mathrm{p}<0.05)$.

The second discriminated function is made of the following: irregular attendance $(-0.388, \mathrm{p}<0.05)$, poorly expressed confrontation with peers $(-0.212, \mathrm{p}<0.05)$, the propensity to run away from home $(-0.282, \mathrm{p}<0.05)$ and suicide behavior $(-0.258, \mathrm{p}<0.05)$, activity disorder $(-0.082, \mathrm{p}<0.05)$.

Table 5 presents the group centroids. The adolescents from non-alcoholic families have the greatest negative group average for the first discriminated function $(-1.62)$ and a low average for the second discriminated function (0.038).

The adolescents from families with untreated alcoholism have a higher group average for the first discriminated function (0.966) and mean average for the second group discriminated function (0.457).

The adolescents from families with treated alcoholism have the greatest negative group average for the second discriminated function (-0.898). At adolescents from families with treated alcoholism a high group average is received for the first discriminated function (0.794), slightly lower than the average the adolescents from families with untreated alcoholism (0.966).

Table 6 shows the results of patient classification in the obtained discriminative functions.

Based on the results in Table 6, we can conclude that $71.5 \%$ of test subjects are correctly classified: $62.9 \%$ of adolescents from families with untreated alcoholism, $89.7 \%$ of the adolescents in the control group and $58.5 \%$ of the youth 
from families with treated alcoholism.

The results indicate the possibility of existence of the specific personality profile of the adolescents from alcoholic families and the youth who have grown up in families without alcoholism or other dysfunctional family systems.

By using analysis of variance (ANOVA) on discriminated functions (Table 7) as dependent variables, we obtained statistically significant differences between samples, in relation to both discriminated functions $(\mathrm{F}=288.125$, $\mathrm{p}<0.001, \mathrm{~F}=22.019, \mathrm{p}<0.001)$.

The data in Table 8 shows the results of Fisher's LSD test about the differences in sub-samples discriminated function.

Fisher's test of least quartered differences shows that the test subjects in control group, the adolescents from non-alcoholic families, have a higher average for the first and the second discriminated functions, compared with the adolescents from alcoholic families (families with treated and untreated alcoholism, $\mathrm{p}<0.001$ ).

The results show that the adolescents from families with untreated alcoholism differ significantly in the second discriminated function $(\mathrm{p}<0.001)$, compared to the adolescents from families with treated alcoholism.

This data explores associations between the growing up in alcoholic dysfunctional families with the specific cognitive, emotional, social, behavioral functioning and psychological char- acteristics of the adolescents which is opposed to the psychological characteristics of the adolescents from non-alcoholic families.

\section{DICSUSSION}

On the first discriminated function the greatest negative group average have adolescents from non-alcoholic family. It can be concluded that adolescents from non-alcoholic families have a predominance of mature behavior, achieved identity and integrity of the person, the need for cooperation and selfless helping to other people, achieved control of aggressive and anxious reactions (offense and defense), coordination of conative and cognitive processes (regulator of integrative reaction), which is expressed in socially adapted behavior. In relationships with people, young from non-alcoholic families express trust, honesty and moderate obstinacy. In setting and meeting school goals and commitments, young from non-alcoholic families have expressed: the ability of paying attention, orientation towards the future and the desire to progress to a personal and professional level; handling of failure, respect of school rules of conduct, which are accompanied by the showing an interest for school and school achievement.

Adolescents from non-alcoholic families do not have expressed phobias, psychosomatic reactions, hyperactive 
behavior, the tendency to try drugs and drinking. The obtained results of the low average of the second discriminated function from non-alcoholic families indicate that adolescents from non-alcoholic families are less absent from school, they have fewer conflicts with peers, the lesser number of the penalties imposed, or activity disorders, as well as suicide attempts or running away from the parental homes.

Adolescents from families with untreated alcoholism have a higher group average on the first discriminated function. It can be concluded that these are adolescents who have: mature attitude with occasional regressions, lack of cooperation, trust and selfless desire to help other people. Expressed aggressive $^{[6,18,33]}$, psychosomatic ${ }^{[34]}$, anxiety and phobic reactions ${ }^{[35]}$, hinder the coordination and integration of regulatory functions, weakening the ability of social adaptation ${ }^{[36]}$. Obstinacy, hyperactive behavior ${ }^{[33,37]}$, and a lower level of tolerance are bringing adolescents from alcoholic families to solve problems by excessive use of alcohol and drugg ${ }^{[38]}$. Problems in sustaining attention ${ }^{[39]}$, lack of interest in school, lack of respect for school rules ${ }^{[40]}$ lead adolescents from families with untreated alcoholism to lower achievement in education, or to be less oriented to the future and planning to accomplish their life goals both in personal and professional. The obtained middle group average in the second dis- criminated function $(0,457)$ of adolescents from families with untreated alcoholism leads to the conclusion that the adolescents of this sub-sample tend to: conflicts with peers ${ }^{[13,26]}$, truancy, running away from home $e^{[6,7,23]}$, suicide attempts ${ }^{[41]}$, depression and posttraumatic stress symptoms ${ }^{[42]}$.

Adolescents from families with treated alcoholism have the greatest negative group average in the second discriminated function (-0.898). Compared with adolescents from families with untreated alcoholism and non-alcoholic families, adolescents from families with treated alcoholism, have the highest absenteeism from school, often conflicts with peers ${ }^{[13]}$ and the tendency to solve problems by suicide attempts ${ }^{[15-18]}$, or by running away from home, or by depressive or hypo-manic behavior ${ }^{[6,7,11-15]}$.

Expression of these personality dimensions indicates that the families of alcoholic with treated alcoholism are alcohol-specific ${ }^{[5]}$, because due to the strong dysfunctionality of all parts of family systems, they are often going for treatment. The increased tendency of adolescents towards abandoning families with treated alcoholism is a reaction to the size of expressed family system disorder, caused by parent's alcoholism and pressure of family members to his medical treatment ${ }^{[13]}$. It is obtained high group percentage at the first discriminated function at adolescents from families with treated alcoholism, which is a 
slightly lower than the percentage of adolescents from families with untreated alcoholism.

It can be concluded that adolescents from families with treated alcoholism, people with: immature behavior, lack of cooperation and trust in people. In cognitive functioning there are moderately significant changes in the regula-

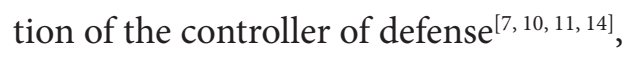
assault $^{[8-10]}$, bodily reaction ${ }^{[19,23]}$, which disrupts the coordination, integration and social adaptation ${ }^{[6,7,21]}$. Propensity for lying, stubbornness, hyperactive ${ }^{[8]}$ and intolerant behavior, leading to non-compliance with school rules ${ }^{[26,27]}$, frequent imposition of educational and disciplinary measures, alcohol and drug abuse $^{[11,18,24]}$.

The prominent attention problems and a lack of interest in school lead to poorer success ${ }^{[27]}$ in learning and less orientation to the future ${ }^{[26,27]}$. Tendency to abulic, depressed or hypomanic behavior was present in a small number of adolescents from families with treated alcoholism.

Based on the results in, we can conclude that $62.9 \%$ of adolescents from families with untreated alcoholism, $89.7 \%$ of adolescents in the control group and $58.5 \%$ of adolescents from families with treated alcoholism are correctly classified. The results indicate the possibility of the existence of specific psychological characteristics of adolescents from alcoholic families ${ }^{[43]}$, as op- posed to the psychological characteristics of adolescents, who have grown up in families without alcoholism or other dysfunctional family systems.

This data have demonstrated the associations between parental alcoholism and personality subtypes of adolescents-COAs, compared to the psychological characteristics of the adolescents from functional non-alcoholic families.

\section{CONCLUSION}

Research suggests that growing up in a dysfunctional alcoholic family system, which damages multiple basic dimensions, communication and cohesion between subsystems and the exercise of parental roles, is associated with academic, cognitive, social, emotional, and behavioral problems, and specific psychological characteristics of adolescents in relation to the psychological characteristics of the adolescents from functional non-alcoholic families. The psychological characteristics of adolescents from alcoholic family consist of: lower level of development of a mature personality, reduced cooperation with people, expressed aggressive and dissociative reactions. The adolescents from families with treated alcoholism and from alcohol-specific families have more pronounced: truancy, conflicts with peers, suicide behavior, running away from home and disorder activity as opposed to the adolescents from fami- 
lies with untreated alcoholism, which indicates the impact of dysfunctional family systems in the formation of permanent and negative changes in some psychological characteristics.

Growing up in a dysfunctional alcoholic family is accompanied by continuous exposure to negative, stressful and traumatic experiences, which is associated with intensified reactions of attack and defense, but also a weak potential for integrative functions, the formation of maturity and focus on the future achievements. The data illustrated that children and adolescents from alcoholic families represented a category of risk population for developing addiction as well as other mental disorders, which is why their early identification was necessary along with the need for introducing mental-hygienic and psychotherapeutic measures in working with them so as to prevent or reduce the negative consequences of growing up in dysfunctional family systems.
PSIHOLOŠKE

KARAKTERISTIKE

ADOLESCENATA IZ

FUNKCIONALNIH I

DISFUNKCIONALNIH

PORODICA

SA OČEVIMA

ALKOHOLIČARIMA

\section{Ljiljana B. Simonović Grujić}

Gimnazija "Bora Stanković" Vranje, Srbija

UDK: 617.836 .1

\section{Kratak sadržaj}

Uvod. Odrastanje u disfunkcionalnim alkoholičarskim porodicama je povezano sa psihosocijalnim razvojem dece. Porodični alkoholizam se retko ispoljava bez nekog oblika nasilja i agresije. Porodični alkoholizam je povezan sa poremećajima mentalnog zdravlja i poremećajima roditeljstva, i iskustvom dece koje ima široki spektar dugoročnih teškoća $u$ emocionalnom i socijalnom prilagođavanju, uključujući i probleme ponašanja 
Cilj. Cilj istraživanja je da odredi povezanost odrastanja u disfunkcionalnoj porodici, izazvano očevim alkoholizmom, sa postignućem psihološke zrelosti, školskim uspehom, internalizovanim, eksternalizovanim i problemima u ponašanju i specifičnih psiholoških karakteristika adolescenata (dece alkoholičara) u poređenju sa psihološkim karakteristikama adolescenata iz funkcionalnih, nealkoholičarskih porodica (deca nealkoholičara).

Metod. Istraživanje je rađeno na uzorku od 691 adolescenta, starosti od 14-19 godina, koji je podeljen u dve grupe: eksperimentalne grupe - 397 adolescenata iz porodica sa alkoholizmom i kontrolne grupe 294 ispitanika iz funkcionalnih porodica u kojima nema alkoholizma ili nekog drugog mentalnog poremećaja roditelja. $\mathrm{Na}$ osnovu tretiranja alkoholizma, eksperimentalna grupa je podeljena u dva poduzorka: 142 adolescenta iz porodica sa lečenim i 255 adolescenata iz porodica sa nelečenim alkoholizmom. Za ispitivanje konativnog funkcionisanja ličnosti korišćena je baterija Kibernetički model konativnih dimenzija ličnosti (KON-6), psihološka zrelost je merena Skalom latentne zrelosti (SLZ), Upitnikom za ispitivanje psihosocijalnih karakteristika mladih i porodice (CPRS-R) je ispitivani uspeh i ponašanje u školi i psihosocijalni razvoj, i opšteintelektualne sposobnosti su merene Testom rezonovanja likova (TRL). Kanoničkom diskriminativnom anali- zom je ispitivana razlika između psiholoških karakteristika ličnosti adolescenata iz alkoholičarskih i nealkoholičarskih porodica.

Rezultati. Studija je utvrdila postojanje statistički značajne razlike između psiholoških karakteristika adolescenata iz alkoholičarskih i nealkoholičarskih porodica. Specifične psihološke karakteristike adolescenata iz alkoholičarskih porodica su: niski nivo psihološkog razvoja zrelosti ličnosti, smanjena saradnja sa ljudima, agresivne i disocijativne reakcije. Kod adolescenta iz porodica sa lečenim porodičnim alkoholizmom izraženo je: besposličenje, sukob sa vršnjacima, suicidalno ponašanje, bežanje od kuće, poremećaji afektiviteta (hipomanično i abulično ponašanje), u poređenju sa adolescentima iz porodica sa nelečenim alkoholizmom. Odrastanje u disfunkcionalnom alkoholičarskom porodičnom sistemu je povezano sa formiranjem specifičnog psihološkog funkcionisanja, internalizovanim, eksternalizovanim i bihevioralnim problemima.

Zaključci. Studija ukazuje na povezanost odrastanja u disfunkcionalnoj alkoholičarskoj porodici sa razvojem specifičnih psiholoških karakteristika adolescenata, u poređenju sa njihovim vršnjacima iz nealkoholičarskih porodica.

\section{Ključne reči:}

disfunkcionalna, porodica, psihološko, adolescenti, alkoholizam 


\section{APPENDIX}

Table 1

Tests of Equality of Group Means

\begin{tabular}{|c|c|c|c|c|c|}
\hline Psychological characteristics & Wilks & Lambda & $F$ & df1 & df2 \\
\hline Cooperation & .685 & 136.410 & 2 & 594 & $.000 * * *$ \\
\hline Frustration tolerance & .897 & 34.227 & 2 & 594 & $.000 * * *$ \\
\hline Trust in people & .842 & 55.615 & 2 & 594 & $.000 * * *$ \\
\hline Selflessness & .815 & 67.246 & 2 & 594 & $.000 * * *$ \\
\hline Attitude towards the future & .811 & 69.111 & 2 & 594 & $.000 * * *$ \\
\hline Maturity & .635 & 170.381 & 2 & 594 & $.000 * * *$ \\
\hline Activity reactions & .991 & 2.622 & 2 & 594 & $.000 * * *$ \\
\hline Psychosomatic reactions & .794 & 76.916 & 2 & 594 & $.000 * * *$ \\
\hline Anxiety reactions & .832 & 60.066 & 2 & 594 & $.000 * * *$ \\
\hline Aggressive Reactions & .762 & 92.551 & 2 & 594 & $.000 * * *$ \\
\hline Dissociative reactions & .752 & 97.899 & 2 & 594 & $.000 * * *$ \\
\hline Integrative reactions & .777 & 85.465 & 2 & 594 & $.000 * * *$ \\
\hline Success in school & .905 & 31.190 & 2 & 594 & $.000 * * *$ \\
\hline Justified absence from school & .814 & 67.801 & 2 & 594 & $.000 * * *$ \\
\hline Drinking problem & .889 & 37.073 & 2 & 594 & $.000 * * *$ \\
\hline Drunkenness & .836 & 58.367 & 2 & 594 & $.000 * * *$ \\
\hline Problems of paying attention & .877 & 41.511 & 2 & 594 & $.000 * * *$ \\
\hline Disinterested students & .946 & 16.807 & 2 & 594 & $.000 * * *$ \\
\hline Hyperactivity & .906 & 30.709 & 2 & 594 & $.000 * * *$ \\
\hline Lying & .892 & 35.886 & 2 & 594 & $.000 * * *$ \\
\hline Phobias & .869 & 44.584 & 2 & 594 & $.000 * * *$ \\
\hline Obstinacy & .777 & 85.434 & 2 & 594 & $.000 * * *$ \\
\hline Conflict with peers & .928 & 23.208 & 2 & 594 & $.000 * * *$ \\
\hline Drug abuse & .982 & 5.591 & 2 & 594 & $.000^{* * *}$ \\
\hline Punishment in school & .907 & 30.596 & 2 & 594 & $.000 * * *$ \\
\hline Running away from home & .957 & 13.250 & 2 & 594 & $.000 * * *$ \\
\hline Suicide behavior & .961 & 11.940 & 2 & 594 & $.000 * * *$ \\
\hline
\end{tabular}


Table 2

Box with M- Test of Equality of Covariance Matrices

\begin{tabular}{c|c|c|c}
\hline Box’s M-Test & $\mathrm{df1}$ & $\mathrm{df2}$ & $\mathrm{p}$ \\
\hline 1570.755 & 378 & 241407.141 & $.000^{* * *}$ \\
\hline \hline
\end{tabular}

Table 3

Canonical discriminated functions, chi-square, and significance

\begin{tabular}{c|c|c|c|c|c|c|c} 
Function & $\begin{array}{c}\text { Eigen } \\
\text { value }\end{array}$ & $\begin{array}{c}\% \text { of } \\
\text { Variance }\end{array}$ & $\begin{array}{c}\% \text { of } \\
\text { Cumulative }\end{array}$ & $\begin{array}{c}\text { Canonical } \\
\text { correlation }\end{array}$ & Chi-square & $\mathrm{df}$ & $\mathrm{p}$ \\
\hline 1 & $1.477(\mathrm{a})$ & 84.5 & 84.5 & .772 & 666.443 & 54 & $.000^{* * *}$ \\
\hline 2 & $.271(\mathrm{a})$ & 15.5 & 100.0 & .462 & 139.336 & 26 & $.000^{* * *}$ \\
\hline \hline
\end{tabular}

Table 4

Structure Matrix

\begin{tabular}{|c|c|c|c|c|c|}
\hline \multirow[b]{2}{*}{$\begin{array}{l}\text { Psychological } \\
\text { characteristics }\end{array}$} & \multicolumn{2}{|c|}{ Function } & \multirow[b]{2}{*}{$\begin{array}{l}\text { Psychological } \\
\text { characteristics }\end{array}$} & \multicolumn{2}{|c|}{ Function } \\
\hline & 1 & 2 & & 1 & 2 \\
\hline Maturity & $-.623^{*}$ & .061 & Lying & $.281^{*}$ & -.121 \\
\hline Cooperation & $-.552^{*}$ & .188 & Frustration tolerance & $-.279 *$ & .000 \\
\hline Aggressive reactions & $.459 *$ & .030 & Alcohol drinking & $.270 *$ & .254 \\
\hline Dissociative reactions & $.449 *$ & .343 & Hyperactivity & $.264^{*}$ & .017 \\
\hline Obstinacy & $.434^{*}$ & .180 & Success in school & $-.264 *$ & -.092 \\
\hline Integrative reactions & $.411^{*}$ & .378 & Punishment in school & $.263^{*}$ & -.048 \\
\hline Psychosomatic reactions & $.398^{*}$ & .305 & Disinterested student & $.189 *$ & -.122 \\
\hline Attitude towards the future & $-.397^{*}$ & -.001 & Drug abuse & $.106 *$ & .089 \\
\hline Selflessness & $-.391 *$ & .037 & \multirow{2}{*}{$\begin{array}{l}\text { Justified absence } \\
\text { from school }\end{array}$} & \multirow[t]{2}{*}{.356} & \multirow[t]{2}{*}{$-.388^{*}$} \\
\hline Anxiety reactions & $.361^{*}$ & .187 & & & \\
\hline Drunkenness & $.358^{*}$ & .158 & Running away from home & .125 & $-.282^{*}$ \\
\hline Trust in people & $-.344^{*}$ & -.216 & Suicide behavior & .123 & $-.258^{*}$ \\
\hline Phobias & $.317^{*}$ & -.080 & Conflict with peers & .211 & $.212^{*}$ \\
\hline Attention disorder & $.306^{*}$ & .066 & Reactions of activity & -.069 & $-.082 *$ \\
\hline
\end{tabular}


Table 5

Functions of Group Centroids

Functions

\begin{tabular}{l|c|c} 
Type of Family & 1 & 2 \\
\hline Non-alcoholic family & -1.620 & .038 \\
\hline Treated alcoholic & .966 & .457 \\
\hline Untreated alcoholic & .794 & -.898 \\
\hline \hline
\end{tabular}

Table 6

Results of classification

\begin{tabular}{|c|c|c|c|c|c|}
\hline & & Type of Family & $\begin{array}{l}\text { Non-alcoholic } \\
\text { family }\end{array}$ & $\begin{array}{l}\text { Untreated } \\
\text { alcoholism }\end{array}$ & $\begin{array}{l}\text { Treated } \\
\text { alcoholism }\end{array}$ \\
\hline \multirow[t]{6}{*}{ Original } & \multirow[t]{3}{*}{$\mathbf{f}$} & Non-alcoholic family & 192 & 10 & 12 \\
\hline & & Untreated alcoholism & 20 & 156 & 72 \\
\hline & & Treated alcoholism & 15 & 41 & 79 \\
\hline & \multirow[t]{3}{*}{$\%$} & Non-alcoholic family & 89.7 & 4.7 & 5.6 \\
\hline & & Untreated alcoholism & 8.1 & 62.9 & 29.0 \\
\hline & & Treated alcoholism & 11.1 & 30.4 & 58.5 \\
\hline
\end{tabular}

Note: The results of classified are in bold.

Table 7

Results of ANOVA

\begin{tabular}{c|c|c|c} 
Function & $\mathbf{F}$ & $\mathrm{df}$ & $\mathbf{p}$ \\
\hline 1 & 288.125 & 2 & $.000^{* * *}$ \\
\hline 2 & 22.019 & 2 & $.000^{* * *}$ \\
\hline \hline
\end{tabular}


Table 8

Fisher LSD test

\begin{tabular}{c|c|c|c|c}
\hline \multirow{2}{*}{1} & Group with Higher $\mathbf{M}$ & Group with Lower $\mathbf{M}$ & Difference $\mathbf{M}$ & $\mathbf{p}$ \\
\hline & Control group & Untreated alcoholism & 1.943 & $.000^{* * *}$ \\
\cline { 2 - 5 } & & Treated alcoholism & 1.637 & $.000^{* * *}$ \\
\cline { 2 - 5 } & Treated alcoholism & Untreated alcoholism & .306 & $.004^{* *}$ \\
\hline \multirow{2}{*}{2} & Untreated alcoholism & Control group & .185 & $.031^{*}$ \\
\cline { 2 - 5 } & & Treated alcoholism & .690 & $.000^{* * *}$ \\
\cline { 2 - 5 } & Control group & Treated alcoholism & .505 & $.000^{* * *}$ \\
\hline \hline
\end{tabular}

\section{REFERENCES / REFERENCE:}

1. Sartorius N, Kaelber CT, CooperJE, Roper MT, RaeDS, Gulbinat W, UstunTB, Regier DA. Progress toward achieving a common language in psychiatry. Results from the field trial of the clinical guidelines accompanying the WHO classification of mental and behavioral disorders in ICD-10. Archives of general psychiatry1993; 50(2): 115-24. DOI:10.1001/ archpsyc.1993.01820140030003.

2. DSM-IV Codes are the classification found in the Diagnostic and Statistical Manual of Mental Disorders. 2014. https://en.wikipedia. org/wiki/DSM-IV_codes.

3. Pearson MR, D'Lima GM, Kelley ML. Self-regulation as a buffer of the 
relationship between parental alcohol misuse and alcohol-related outcomes in first-year college students. Addictive Behaviors 2011; 36(12): 1309-12. DOI: 10.1016/j.addbeh 2011.07.009.

4. Oscar-Berman M, Valmas MM, Sawyer KS, Ruiz SM, Luhar RB, Gravitz ZR. Profiles of impaired, spared, and recovered neuropsychologic processes in alcoholism. Handb Clin Neurol 2014; 125: 183-210. DOI: 10.1016/B978-0-444-62619-6.000124.

5. Winokur G, Rimer J, Reich T. Alcoholism IV: Is there more than one type of alcoholism. Journal Psychology 1997; 118(546): 525-31. DOI: 10.1192/bjp.118. 546. 525.

6. Vail MO, Protinsky H, Prouty A. Samling issues in research on adult children of alcoholics: Adolescence and beyond. Adolescence 2000; 35(137): 113-19. PMID: 10841300.

7. Choi DH, Kim JS, Jung JG, Ryou YL, Kim YS, Uh WC. The role of parental drinking problems in psychological characteristics of high school students. Korean J Fam Med 2013; 34(6): 377-84. DOI: 10.4082/ kftm.2013.34.6.377.

8. Fuller BE, Chermack ST, Cruise KA, Kirch E, Fitzgerald HE, Zucker RA. Predictors aggression across three generations among sons of alcoholics:Relationships involving grandparental and parental alcoholism, child aggression, marital aggression and parenting paractices. Journal of Studies on Alcohol 2003; 64(4): 472-83. PMID: 12921189

9. Hussong $A M$, Huang $W$, Curran
PJ, Chassin L, Zucker RA. Parent alcoholism impacts the severity and timing of children's externalizing symptoms. Abnormal Child Psycho: An official publication of the International Society for Research in Child and Adolescent Psychopathology 2010; 38(3): 36780. DOI: $10.1007 / \mathrm{s} 1082-009-9374-5$.

10. Bountress K, Chassin L. Risk for behavior problems in children of parents with substance use disorders. Am J Orthopsychiatry 2015; 85(3): 275-86. DOI: $10.1037 /$ ort0000063.

11. Kingree JB, Thompson M. Matural help groups, perceived status benefits, and well-being: A test with adult children of alcoholics with personal substance abuse problems. American Journal of Community Psychology 2000; 28(3): 325-42. www.ncbi.nlm.nih.gov > NCBI > Literature > PubMed Central (PMC)

12. Balsa A. Parental problem-drinking and adult children's labor market outcomes. Journal of Human Resourses 2008; 43(2): 454-86. DOI: 10.3368/jhr.43.2.454.

13. Rounsaville D, O'Farrell TJ, Andreas JB, Murphy CM, Murphy MM. Children's exposure to parental conflict after father's treatment for alcoholism. Addict Behav 2014; 39(7): 1168-71. DOI: 10.1016/j. addbeh.2014.03.017.

14. Lease SH. A model of depression in adult children of alcoholics and nonalcoholics. Journal of Counseling and Development 2002; 80(4): 44151. DOI: 10.1002/j.1556-6678.2002. tb00211.x.

15. Silva RR, Alpert M, Munoz DM, Singh 
S, Matzner F, Dummit S. Stress and vulnerability to posttraumatic stress disorder in children and adolescents. American Journal of Psychiatry 2000; 157: 1229-35. http://dx. DOI. org/10. 1176/appi.ajp. 157.8. 1229.

16. Enlow MB, Blood E, Egeland BJ. Socio demographic risk, developmental competence, and PTSD symptoms in young children exposed to interpersonal trauma in early life. Trauma Stress 2013; 26(6): 686-94. www.ncbi.nlm. nih.gov/ pubmed/ 24490247.

17. Mackrill T, Hesse M. Suicide behavior in parents with alcohol abuse problems and suicide behavior in their offspring-adult offspring and counselor perspectives. Nord J Psychiatry 2012; 66(5): 343-8.www. ncbi.nlm.nih.gov/pubmed/22283687

18. Serec M, Svab I, Kolšek M, Svab V, Moesgen D, Klein M. Health-related lifestyle, psysical and mental health in children of alcoholic parents. Drug Alcohol Rev 2012; 31(7): 861-70. DOI: 10.1111/j. 1465-3362.2012.00424.x.

19. Obot IS, Anthony JC. Mental health problems in adolescent children of alcohol dependent parents: Epidemiologic research with a nationally representative sample. Journal of Child \& Adolescent Substance Abuse 2004; 13(4): 83-96. https:// books. google.rs/ books?isbn=1134702736.

20. Jaeger E, Hahn NB, Weinraub M. Attachment in adult daughters of alcoholic fathers. Addition 2000; 95(2): 267-76. DOI: 10.1046/j.13600443.2000.95226713.x.

21. Simonović Lj. Emocionalna zrelost dece alkoholičara. Beograd: ZbornikZdravstveno ponašanje studentske i srednjoškolske omladine ZZZS 2000; 4(2): 156-60.

22. Watt TT. Marital and cohabiting relationships of adult children of alcoholics: Evidence from National Survey of Families and Households. Journal of Family 2002; 23(2): 246-65. DOI: 10.1177/0192513X02023002004.

23. Cuijpers $P$, Steunenberg B, Van Straten A. When children of problem drinkers grow old: Does the increased risk of mental disorders persist? Addictive Behaviors 2006; 31(12): 2284-91. DOI:10.1016/j. addbeh.2006.03.003.

24. Hall J. Childhood perceptions of family, social support, parental alcoholism, and later alcohol use among African American college students. Journal of Substance Use 2010; 15(3): 157-65. DOI:10.1111/ j.1360-0443.2012.03903.x 4.60.

25. Cservenka A, Herting MM, Nagel BJ. Atypical frontal lobe activity during verbal working memory in youth with a family history of alcoholism. Drug and Alcohol Dependence 2012; 123: 98-104. DOI:10.106/ jdrugdcdep.2011.10.021.

26. Miler LS, Wasserman GA, Neugebaurer R, Gorman-Smith D, Kombounkos D. Witnessed community violence and antisocial behavior in high-risk, urban boys. Journal of Clinical Child Psychology 1999; 28(1): 2-11. DOI: $10.1207 / \mathrm{s}$ 15374424 jccp2801_1.

27. Sayette MA, Martin CS, Perrott MA, Wertz JM. Parental alcoholism and 
the effects of alcohol on mediated semantic priming. Experimental and Clinical Psycho pharmacology 2001; 9(4): 409-17. http://dx.doi.org/ 10.1037/1064-1297. 9. 4.409.

28. Waters FC, Twaite JA. Adult children of alcoholics: personality profil. An empirical test. Washington: National Couvic on Alc 1985. www. techbook. com.tw/File/Book/ 17106R.

29. Conners K, Sitarenios G, Parker JDA, Epstein J. The Revised Conners, Parent Rating Scale (CPRS-R): Factor Structure, Reliability, and criterion Validity. Journal of Abnormal Child Psychology 1998; 26(4):257-668. PMC4217462. https://www.ucl. ac.uk/.../mental_health_outcome_ measures_for_children.

30. Potočnik-Bele Ž, Hruševar B, Tušak $M$. Test rezonovanja likova-TRL. Ljubljana: Zavod SR Slovenije za produktivnost dela 1984.

31. Hrnjica S. Zrelost ličnosti. Beograd: Zavod za izdavanje udžbenika i nastavna sredstva 1992: 35-198.

32. Momirović K,Wolf B, Džamonja Z. KON-6 Kibernetički model ličnosti. Beograd: SDPS-Centar za prmenjenu psihologiju 2002-2015.

33. Waln K. Brown, Ph.D. Thomas A. Newman B.S. Robert M. Wilson, Ph.D. Children of alcoholic families. William Gladden Foundation, 2005.

34. Holmes MR. Aggressive behavior of children exposed to intimate partner violence: an examination of maternal mental health, maternal warmth and child maltreatment. Child Abuse Negl 2013; 37(8): 520-30. DOI: 10.1016/j. chiabu.2012.12.006.

35. Díaz R, Gual A, García M, Arnau J,
Pascual F, Cañuelo B, Rubio G, de Dios Y, Fernández-Eire MC, Valdés R, Garbayo I. Children of alcoholics in Spain: from risk to pathology. Results from the ALFIL program. Soc Psychiatry Psychiatr Epidemiol 2008; 43(1): 1-10. DOI: 10.1007/s00127007-0264-2.

36. Eiden RD, Colder C, Edwards EP, Leonard KE. A longitudinal study of social competence among children of alcoholic and nonalcoholic parents: role of parental psychopathology, parental warmth, and self-regulation. Psychol Addict Behav 2009; 23(1): 36-46.

37. Andreas JB, O'Farrell TJ. Longitudinal Associations Between Fathers' Heavy Drinking Patterns and Children's Psychosocial Adjustment, Journal of Abnormal Child Psychology 2007; (35): 1-16.

38. Melchior, M., Choquet, M, Le Strat, Y., Hassler, C. and Gorwood, P. Parental alcohol dependence, socioeconomic disadvantage and alcohol and cannabis dependence among young adults in the community. European Psychiatry 2011; (26): 13-17.

39. Poon E, Ellis DA, Fitzgerald HE, Zucker RA. Intellectual, cognitive, and academic performance among sons of alcoholics, during the early school years: differences related to subtypes of familial alcoholism. Alcohol Clin Exp Res 2000; 24(7): 1020-27. 40.Zanoti-Jeronymo DV, Carvalho AM. Self-concept, academic performance and behavioral evaluation of the children of alcoholic parents. Rev Bras Psiquiatr 2005; 27(3): 233-6. 41. Liu YY, Wang XT, Qiu HM, Xu AQ, Jia 
CX. Functional and dysfunctional impulsivity and attempted suicide in rural China: A paired case-control study. Psychiatry Res 2017; 253: 22-27. DOI: 10.1016/j.psychres. 2017.03.025.

42. Brown-Rice KA, Scholl JL, Fercho KA, Pearson K, Kallsen NA, Davies GE, Ehli EA, Olson S, Schweinle A, Baugh LA, Forster GL. Neural and psychological characteristics of college students with alcoholic parents differ depending on current alcohol use. Prog Neuropsychopharmacol Biol Psychiatry. 2018 Feb 2;81:284-296. DOI: 10.1016/j.pnpbp.2017.09.010.

43. Hinrichs J, Defife J, Westen D. Personality subtypes in adolescent and adult children of alcoholics: a two-part study. J Nerv Ment Dis 2011; 199(7): 487-98. DOI: 10.1097/ NMD.0b013e3182214268.

Ljiljana B. Simonović Grujić

Gimnazija "Bora Stanković", Partizanska 12, 17000 Vranje, Srbija

ljiljanasimon@gmail.com 